\title{
FENOMENA HIJAB DALAM BISNIS KULINER DI KOTA MEDAN
}

\author{
Marzuti Isra \\ iramarzutiisra@yahoo.com \\ Sekolah Tinggi ilmu Pertanian Perkebunan (STIPAP) LPP Medan. \\ Sri Sudiarti \\ Isnaini Harahap \\ isnaini.harahap@uinsu.ac.id \\ UIN Sumatera Utara
}

\begin{abstract}
This study aims to describe about the use of hijab to women who work in culinary business Medan City. This research uses qualitative method whose data is descriptive analytical. The objects of this research are owners and female workers at the Bika Ambon Zulaikha and Bolu Meranti outlets. The research is using qualitative method with descriptive analytic data and collection by interviewing, observing and documenting techniques. The results of the study show that (1) Working with women workers is a policy applied by culinary investors for the purpose of implementing marketing management strategies in attracting the largest Muslim consumers in Medan and maintaining clean and hygienic environment for all culinary products. (2) Awareness of the veil of every female worker which are an ideological awareness and understanding long before work, find awareness and understanding of hijab after work also the awareness and understanding of the hijab is limited as the head cover to maintain the cleanliness of culinary products. (3) Hijab also contributes in building the perception of Islamic consumers to shop at culinary outlets. That Islamic consumers have the confidence and convenience of hygienic and halal guarantees when shopping for culinary at outlets whose workers use the hijab.
\end{abstract}

\section{Keyword: Hijab, culinary, business, female, workers}

\begin{abstract}
Abstrak
Penelitian ini bertujuan untuk menjawab pertanyaan tentang penggunaan jilbab bagi wanita yang bekerja di bisnis kuliner Kota Medan.Objek penelitian ini adalah pemilik dan pekerja perempuan di toko Bika Ambon Zulaikha dan Bolu Meranti. Penelitian ini menggunakan metode kualitatif yang datanya bersifat deskriptif analitis dan teknik pengumpulan data dengan wawancara, observasi dan dokumentasi. Hasil penelitian, yaitu (1) Bekerja dengan pekerja perempuan adalah kebijakan yang diterapkan oleh investor kuliner dengan tujuan sebagai implementasi strategi manajemen pemasaran dalam menarik konsumen muslim terbesar di Medan dan menjaga kebersihan lingkungan dan higienis untuk semua produk kuliner. (2) Kesadaran tabir setiap pekerja perempuan, yaitu pemahaman ideologis sebelum bekerja, pemahaman ideologis setelah bekerja dan pemahaman tentang hijab sebagai penutup kepala untuk menjaga kebersihan produk kuliner. (3) Hijab juga berkontribusi dalam membangun persepsi konsumen Islam untuk berbelanja di outlet kuliner di mana konsumen Islam memiliki kepercayaan diri
\end{abstract}


dan kenyamanan jaminan higienis dan halal saat berbelanja kuliner di gerai yang pekerja menggunakan jilbab.

Kata kunci : hijab, kuliner, bisnis, pekerja, perempuan

\section{Pendahuluan}

Bisnis kuliner bukan ide baru, bahwa sejak lama Kota Medan memang sudah terkenal dengan ciri khas kulinernya. Namun bisnis kuliner menjadi salah satu sektor favorit yang dikembangkan oleh investor besar maupun kecil disebabkan oleh pertumbuhan pembangunan di Kota Medan yang bergerak cepat. Sehingga bisnis kuliner di Kota Medan yang sebelumnya berbasis pada kuliner dengan gaya dan metode tradisional hadir kembali menjadi gaya dan metode yang lebih modern. Sebagai contoh, mie sop sebelumnya adalah jenis jajanan masyarakat menengah ke bawah, sekarang mei sop menjadi jajanan yang mampu menyerap konsumen dari latar belakang menengah atas. Seperti yang terlihat Mie Sop Kampung di jalan Gagak Hitam/Ringroad Medan, sangat ramai dikunjungi oleh pencinta kuliner.

Perkembangan dan percepatan bisnis di sektor kuliner telah menjadikan Medan sebagai kota yang multikultural memiliki trademark sebagai kota tujuan kuliner di Indonesia, sering juga disebut sebagai kota wisata kuliner. Kemajemukan ciri sosial dan budaya lokal penduduk kota turut membentuk berbagai cita rasa masakan khas daerah yang didukung sumber daya alam yang hinterland kota. Artinya keterpaduan dan kombinasi kekayaan khasanah budaya lokal tersebut tentunya mempengaruhi warna warni cita rasa khas daerah dalam bisnis kuliner di Kota Medan. ${ }^{1}$

Selain bisnis di sektor manufaktur dan sektor-sektor lain yang berbasis pada kebutuhan tenaga kerja yang banyak, maka bisnis kuliner juga tidak kalah dalam menyerap tenaga kerja, terutama perempuan. Hal ini dapat dimaklumi karena perempuan memiliki keterampilan dan insting yang cukup kuat terkait dengan ilmu tataboga. Tenaga kerja perempuan juga paling tepat untuk melakukan pekerjaan pelayanan terhadap konsumen kuliner, karena pekerjaan pelayanan berhadapan langsung dengan konsumen maka tampilan pekerja perempuan (fashion) menjadi perhatian yang serius bagi para owner. Fashion ${ }^{2}$ pekerja perempuan dapat mewakili karakter dari produk yang ditawarkan. 
Pentingnya fashion dalam dunia usaha karena fashion memiliki beberapa fungsi. Pertama, sebagai sarana komunikasi, fashion bisa menyampaikan pesan artifaktual yang bersifat non-verbal. Fashion bisa merefleksikan, meneguhkan, mengekspresikan suasana. Fashion memiliki suatu fungsi kesopanan (modesty function) dan daya tarik. Sebagai fenomena budaya, fashion sesungguhnya bisa berucap banyak tentang identitas pemakainya. Fashion juga dapat digunakan untuk menunjukkan nilai sosial dan status, karena orang bisa membuat kesimpulan tentang siapa anda, kelompok sosial mana anda, melalui medium fashion. ${ }^{3}$ Kedua, fashion memiliki fungsi sebagai penolong yang memastikan bahwa masyarakat mengadaptasikan kehidupan modern yang kompleks. Karenanya, fashion juga mencermikan aktivitas masyarakat yang dinamis. Kebutuhan individu dan masyarakat dipertemukan melalui fashion. Di satu sisi, individu mendapatkan sesuai dengan yang di kehendaki. Di sisi lain, pada saat bersamaan, masyarakat memperoleh keuntungan yang bersifat ekonomis dari fashion. ${ }^{4}$ Sangat menarik perhatian bahwa belakangan ini muncul fenomena fashion yang bernuansa Islami yaitu penggunaan hijab bagi pekerja perempuan untuk banyak sektor usaha, termasuk kuliner. Saat sedang melakukan wisata kuliner di Kota Medan, untuk kuliner apa saja, dapat dipastikan bahwa akan menjumpai pekerja perempuannya menggunakan busana berbalut hijab.

Untuk perusahaan-perusahaan yang berbasis syariah, penggunaan hijab sebagai fashion kerja untuk para pekerja perempuan Muslim adalah wajar sebagai simbol perwujudan identitas ke-Islamannya. Namun menjadi pertanyaan besar bila usaha kuliner di mana produk yang ditawarkan adalah umum (bisa dikleim milik semua orang) dan tidak berbasis syariah, owner perusahaan tersebut pun tidak beragama Islam, tetapi mengharuskan pekerja perempuannya (muslimah) menggunakan hijab.

Hijab sebagai ikon dan simbol keberagamaan dalam Islam, oleh kapitalisme telah dieksploitasi menjadi produk modernitas dan simbol fashion kekinian..$^{5}$ Tidak berhenti sampai disitu, dalam bisnis kuliner, terutama di Kota Medan, sepertinya kapitalisme juga telah menjadikan hijab sebagai sebuah cara untuk merebut pasar (pelanggan) di tengah-tengah konsumen yang mayoritas beragama Islam. ${ }^{6}$ Hijab yang digunakan oleh hampir seluruh pekerja perempuan (pramusaji) dijadikan simbol bahwa produk yang ditawarkan adalah halal, sesuai dengan labelisasi halal untuk semua produk makanan. 
Penggunaan hijab sebagai fashion pramusaji dalam usaha kuliner di Kota Medan telah menjadi fenomena yang menarik untuk diperhatikan dan terlebih lagi sebagai objek penelitian. Sebab, fenomena penggunaan hijab tidak saja terjadi dan terlihat di perusahaan-perusahaan yang berbasis syariah atau owner yang beragama Islam, tetapi juga terjadi di perusahaan yang ownernya beragama non Muslim.

\section{Pemasaran}

Marketing memang sangat erat kaitannya dengan kegiatan kehidupan kita sehari-hari karena objeknya adalah konsumen. Konsumen bisa dijadikan informasi yang dibutuhkan oleh para Marketer (pemasar) dalam melakukan suatu kegiatan marketing. Apabila seorang pemasar mengerti kebutuhan konsumen, mengembangkan produk yang mempunyai nilai lebih dan melaksanakan penetapan harga, distribusi, dan promosi yang efektif, menjual produk akan lebih mudah. Menurut P.Kotler marketing (pemasaran) adalah suatu proses sosial dan manajerial yang didalamnya individu-individu dan kelompok mendapatkan halhal mereka butuhkan dan inginkan melalui penciptaan, penawaran dan pertukaran (nilai) produk-produk dengan pihak lain. Adapun marketer (pemasar) adalah seorang yang secara aktif mencari sumber daya dari pihak lain dan bersedia menawarkan sesuatu sebagai gantinya. Tugas seorang pemasar adalah "membangun marketing program" untuk mencapai tujuan perusahaan yang diinginkan. ${ }^{7}$

\section{Pemasaran Dalam Islam}

Kata Syariah (al-syariah) telah ada dalam bahasa Arab sebelum turunnya Al-Quran. Kata yang semakna dengannya juga ada dalam Taurat dan Injil. Kata "syari'at" dalam bahasa Ibrani disebutkan sebanyak 200 kali, yang selalu mengisyaratkan pada makna "kehendak Tuhan yang diwahyukan sebagai wujud kekuasaan-Nya atas segala perbuatan manusia". 8 Pasar syariah adalah pasar dimana pelanggannya selain memliki motif rasional juga memiliki motif emosional. Pelanggan tertarik untuk berbisnis pada pasar syariah bukan karena alasan dan keinginan untuk mendapatkan keuntungan finansial semata yang 
bersifat rasional, namun karena keterikatan terhadap nilai-nilai syariah yang dianutnya. Pemasar dan pelanggan dua hal penting dalam melaksanakan aktivitas bisnisnya, yaitu dunia dan akhirat. ${ }^{9}$

Pemasaran menempatkan konsumen sebagai subjek dan tidak hanya sebagai objek pembeli produk perusahaan, sehingga kebutuhan konsumen akan didengarkan dan berusaha untuk mewujudkan. Secara Umum Kertajaya menyatakan bahwa Pemasaran syariah adalah strategi bisnis, yaitu harus memayungi seluruh aktivitas dalam sebuah perusahaan, meliputi proses, menciptakan, menawarkan, pertukaran, nilai, dari seorang produsen, atau satu perusahaan, atau perorangan, yang sesuai dengan ajaran Islam. ${ }^{10}$

\section{Implementasi Syariah Marketing}

Nabi Muhammad SAW sebelum diangkat sebagai Rasulullah telah menggeluti bidang bisnis selama 25 tahun mulai sejak usia 12 tahun. Seperti diketahui Rasulullah berusia 63 tahun yang dengan rincian 12 tahun masa kanakkanak, 25 tahun masa berbisnis, 3 tahun merenungi keadaan masyarakat jahiliah, dan 23 tahun mengemban tugas kerasulan. Jika kita renungi dan dihubungkan dengan strategi pemasaran yang sekarang diagung-agungkan oleh para pelaku bisnis. Sudah sejak abad ke-7 beliau mengajar umatnya bagaimana berdagang yang benar, dan sekarang baru dirasakan betapa indahnya ajaran itu. Beliau sangat mengutamakan perilaku jujur (shiddiq), ikhlas, profesionalisme, silaturrahmi, dan murah hati. Serta nilai-nilai syariah yang menjadi landasan marketing syariah adalah sifat-sifat utama yang dimiliki Rasulullah SAW yaitu Shiddiq, amanah, fathanah, dan thabligh. ${ }^{11}$

\section{Praktik Pemasaran syariah}

Dunia bisnis dengan berbagai perilaku didalamnya dipelopri oleh bisnis Amerika, seakan-akan memisahkan dunia bisnis dengan keyakinan agama. Disini akan dijelaskan bagaimana praktik pemasaran yang dilakukan Rasulullah SAW antara lain sebagai berikut $:^{12}$

a. Segmentasi dan Targeting yaitu dipraktikan beliau tatkala berdagang ke negara syam, Yaman, Bahrain. Beliau mengenal betul barang apa yang disenangi oleh penduduk dan diserap oleh pasar setempat. 


\section{Fenomena Hijab Dalam Bisnis Kuliner Di Kota Medan (Marzuti Isra, Sri 606 Sudiarti dan Isnaini Harahap)}

b. Positioning berarti bagaimana membuat barang yang kita hasilkan atau kita jual memliki keunggulan, disenangi, dan melekat dihati pelanggan dan bisa melekat dalam jangka waktu yang lama. Beliau menjual barang-barang asli yang memang original serta sesuai dengan kebutuhan dan keinginan pelanggan.

c. Marketing Mix (Bauran Pemasaran) ini adalah suatu strategi pemasaran untuk melayani pelanggan dengan cara memuaskannya melalui product, price, place dan promotion (4P).

\section{Fenomena Hijab}

Di Indonesia, istilah hijab atau lebih dikenal dengan sebutan jilbab pada awalnya dikenal sebagai kerudung untuk menutupi kepala (rambut) perempuan hingga dada. Pada perkembangannya, hijab dipandang sebagai sebuah fenomena sosial yang kaya makna dan penuh nuansa. Dalam ranah sosial religius, hijab berfungsi sebagai bahasa yang menyampaikan pesan sosial dan budaya. Bagi perempuan Muslim Indonesia saat ini, hijab seolah-olah hanya menjadi miliknya. Karena hijab telah menjadi identitas bagi perempuan Muslim Indonesia. Hijab merupakan pakaian penutup aurat yang menutupi seluruh tubuh perempuan kecuali wajah dan telapak tangan. ${ }^{13}$

Fenomena semangat keagamaan perempuan muslim dengan menggunakan simbol-simbol ketakwaan seperti hijab, nampaknya benar-benar dimanfaatkan oleh berbagai kalangan bisnis untuk menjual apapun barang konsumsi yang bisa dilekatkan pada momen keagamaan tersebut. Potensi umat Islam sebagai pasar yang menjanjikan ini benar-benar dimanfaatkan oleh berbagai kalangan bisnis untuk menjual apapun barang-barang konsumsi yang biasa dilekatkan pada keagamaan. Industri kuliner, butik, kosmetik dan media bersaing memikat pasar Islam yang demikian besar. Industri dan religi merupakan suatu tema yang sangat berkaitan dengan kapitalisme bahkan menjadi lambang dari kapitalisme itu sendiri. 


\section{Metode Penelitian}

Jenis penelitian ini adalah kualitatif, dengan pendekatan deskriptif analisis. Penelitian ini juga bertujuan menjelaskan fenomena dengan sedalam-dalamnya melalui pengumpulan data. ${ }^{14}$ Subjek pada penelitian ini adalah para pekerja perempuan (pramusaji), yang menggunakan hijab sebagai fashion kerjanya di toko Bika Ambon Zulaikha dan toko Bolu Meranti. Data yang digunakan adalah data primer dan data sekunder. Data primer berupa wawancara dengan objek para pekerja perempuan, pemilik dan konsumen. Serta beberapa keterangan sebagai pelengkap atau informasi tambahan kepada peneliti sebagai bahan pelengkap penelitian seperti buku-buku, jurnal-jurnal, media massa, brosur dan alat-alat peraga sosialisai produk yang mendukung. Teknik analisis data dengan menggunakan model interaktif Huberman dan Miles. Model ini menyebutkan adanya sifat interaktif antara kolektif data atau pengumpulan data dengan analisis data. Analisis data yang dimaksud adalah reduksi data, penyajian data dan verifikasi atau penarikan kesimpulan. Dengan teknik keabsahan data peneliti melakukan proses triangulasi. ${ }^{15}$

\section{Hasil Penelitian}

Bisnis kuliner Bika Ambon mulai dirintis oleh $\mathrm{Hj}$. Mariani tepatnya sejak tanggal 12 Agustus 2003. Hj. Mariani, perempuan paruh baya kelahiran Kota Medan, bersuku Melayu dan beragama Islam ini merupakan pensiunan asisten farmasi (apoteker) Kimia Farma di Kota Medan. Menekuni bisnis kuliner Bika Ambon justru dimulai sejak ia pensiun. Saat Hj. Mariani memutuskan untuk pensiun dan total menekuni bisnis kuliner Bika Ambon, dengan target menarik sebanyak-banyaknya pangsa pasar Muslim, di mana posisi $\mathrm{Hj}$. Mariani melayani langsung konsumennya maka mengharuskan $\mathrm{Hj}$. Mariani untuk memulai memakai hijab yang sebelumnya tidak menjadi busana kesehariannya. Ada beberapa alasan yang disampaikan oleh $\mathrm{Hj}$. Mariani untuk memutuskan berhijab, pertama, komitmennya untuk menarik pangsa pasar Muslim berbelanja di outletnya, kedua, interaksi langsung dengan konsumen terutama Muslimah yang umumnya juga berhijab, ketiga, walaupun bersuku Melayu tetapi kondisi kulitnya yang sangat

putih dan mata yang cenderung cipit, sering sekali dirinya dipandang sebagai orang China dan keempat, hingga kini ia terus menggunakan hijab dengan 
motivasi yang telah bergeser dari urusan bisnis ke perwujudan rasa syukur kepada Alllah karena dengan niat menampilkan simbol-simbol Islam dalam berbisnis ia telah diberikan nikmat rezeki yang melimpah.

Semua pekerja perempuan di outlet Bika Ambon Zulaikha memakai hijab sebagai busana kerja mereka sehari-hari. Menurut keterangan yang peneliti peroleh dari kepala pengawas bernama Emi bahwa kebijakan berhijab bagi pekerja perempuan bukan sebuah kebijakan yang mengikat dari perusahaan tetapi memang ada anjuran untuk berhijab. Secara kebetulan memang, seluruh yang melamar dan diterima bekerja di Bika Ambon Zulaikha adalah Islam dan sejak awal sudah berhijab.

Lalu pemilik yaitu $\mathrm{Hj}$. Mariani melabelkan nama Zulaikha pada Bika Ambon hasil produksinya dan melekatkan simbol-simbol ke-Islaman baik pada dirinya dan karyawannya dengan balutan hijab saat memasarkan produknya turut andil dalam membesarkan bisnisnya. Hj. Mariani mendapatkan momentumnya "mengalahkan" para investor lain yang pada saat bersamaan tidak mampu membuktikan kehalalan dari produknya. Tidak butuh waktu lama bagi Hj. Mariani menjadikan Bika Ambon bermerek Zulaikha untuk booming di seluruh Nusantara Republik Indonesia. Sehingga menjadikan Bika Ambon Zulaikha sebagai salah satu trend mark kuliner Kota Medan.

Popularitas Bika Ambon Zulaikha yang ditopang oleh kualitas cita rasa yang lezat dan melekatnya identitas ke-Islaman yang secara konsisten terus dijaga, membuat Bika Ambon Zulaikha tetap menjadi idola oleh para wisatawan kuliner baik dalam maupun luar Kota Medan. Bika Ambon Zulaikha menjadi salah satu oleh-oleh wajib bagi siapa saja yang berkunjung ke Kota Medan. Hal ini dibuktikan dari pengakuan Pak Ahmad Gojali, "Saya dari Jakarta ke Medan untuk urusan pekerjaan, sengaja datang kemari untuk belanja oleh-oleh buat kelaurga dan teman-teman di kantor. Katanya gak sah ke Medan kalau belum bawa Bika Ambon Zulaikha". ${ }^{16}$ Begitu sangat melekat image Bika Ambon Zulaikha sebagai salah satu oleh-oleh dari Kota Medan.

Menurut Ahmad Ghozali, ada dua alasan utama yang disampaikannya mengapa ia berbelanja di autlet Bika Ambon Zulaikha, pertama, sebagai seorang 
Muslim, dari berbagai autlet Bika Ambon di sepanjang Jalan Majapahit, ia melihat bahwa Bika Ambon Zulaikha sangat kental nuansa ke-Islamannya dan diketahuinya bahwa pemilik usaha ini adalah Islam. Kedua, rasa dan kualitas Bika Ambon Zulaikha cocok untuk selera kulinernya.

Salah satu konsumen lain menyatakan bahwa motivasinya untuk berbelanja di outlet Bika Ambon Zulaikha karena konsumen tersebut mendapatkan jaminan bahwa makanan yang ia makan dan diberikan kepada keluarganya adalah halal. "Maklumlah dek, sekarang ini kan banyak isu makanan yang tidak halal, bercampur lemak babi. Dulu juga kan sudah ada berita tentang Bika Ambon yang dibuat selain disini diragukan kehalalannya. Supaya lebih pasti ya belanja disini saja dek", kata Tika salah seorang konsumen outlet tersebut. ${ }^{17}$ Lebih lanjut, dia juga menjelaskan bahwa Bika Ambon Zulaikha mencerminkan identitas ke-Islaman yang cukup kuat, identitas ini cukup bagi Ibu Tika untuk menilai bahwa seluruh panganan yang di jual aman dari unsur-unsur yang haram.

\section{Bolu Meranti}

Usaha kuliner yang juga telah menjadi ikon dan kebanggaan Kota Medan adalah Bolu Meranti dengan pemilik bernama Ai Ling, seorang perempuan beretnis China dan beragama Non Muslim yang merintis usaha Bolu Meranti ini sejak tahun 2005.

Dari pengamatan yang dilakukan oleh peneliti pada outlet Bolu Meranti kota Medan $^{18}$, terlihat bahwa seluruh pekerja perempuan yang berada di outlet Bolu Meranti menggunakan hijab, mulai dari bagian pemesanan produk sampai pekerja yang khusus melakukan pengepakkan produk, kecuali dibagian kasir. Bagian kasir ini, dari informasi yang peneliti dapat memang langsung dipegang oleh keluarga yang diketahui bukan bergama Islam dan beretnis China.

Terkait dengan hijab yang digunakan oleh seluruh perempuan yang terlihat bekerja di bagian pemasaran, saat dikonfirmasi kepada pihak pengelola, mereka menyatakan bahwa tidak pernah membuat kebijakan berhijab kepada pekerja perempuannya. Pengelola juga menolak ketika peneliti menghubungkan antara hijab dengan strategi pemasaran yang ditujukan untuk menarik konsumen Islam. Menurut pengelola Bolu Meranti, bahwa mereka tidak berpedoman pada busana 
hijab pekerja perempuannya dalam merekrut konsumen yang beragama Islam. Pihak pengelola hanya mengedepankan kualitas produksi, baik dari penampilan, ragam rasa dan terutama kelezatannya. Kalau pekerjanya berhijab lalu konsumen yang beragama Islam berbelanja kemari, itu hanya sebuah kebetulan saja.

“Kami tidak mengharuskan pekerja memakai jilbab. Itu adalah hak dan kepercayaan mereka mau pakai atau tidak, tetapi saat bekerja mereka harus memakai penutup kepala agar bersih dan rambut tidak jatuh dan tidak masuk kedalam makanan. Kalau diluar saya tidak tahu mereka pakai jilbab atau tidak, tetapi pada saat datang bekerja mereka memakai jilbab". ${ }^{19}$ Keharusan menutup kepala saat bekerja dengan tujuan menjaga kebersihan merupakan keharusan yang dilakukan oleh setiap pekerja di Bolu Meranti. Memang salah satu fungsi hijab secara fisik adalah menutup bagian kepala, secara syariat menutup kepala hingga bagian dada.

Keterangan dari pihak pengelola terkait dengan eksistensi hijab sesungguhnya tidak bersesuain dengan fakta-fakta di lapangan. Pertama, ada beberapa pekerja perempuan yang beragama Non Muslim, dan kedua, semua pekerja perempuan Non Muslim ditugaskan bekerja hanya dibagian produksi. Bila memang hijab bukan bagian dari sebuah strategi pemasaran selayaknya akan dijumpai pekerja perempaun yang tak berhijab, baik dengan alasasan Non Muslim, seperti pihak keluarga yang senantiasa mengawasi proses pemasaran, pelayanan dan pembayaran maupun dengan alasan yang lain.

Konsumen Bolu Meranti pada awalnya hanya sebatas keluarga, teman dan etnis China saja yang berada disekitar Kota Medan. Setelah usaha ini populer maka konsumen Bolu Meranti kini telah menjamah dari segala unsur dan lapisan masyarakat, baik dalam kota maupun luar kota, baik etnis China maupun Pribumi, baik Non Muslim maupun Muslim. Konsumen Muslim, sebagaimana pengamatan yang peneliti lakukan cukup signifikan berbelanja Bolu Meranti.

Saat Bolu Meranti sudah menjadi jajanan primadona untuk seluruh masyarakat pencinta kuliner dan melonjaknya jumlah konsumen yang beragama Islam, tentunya hal ini merupakan peluang pasar yang cukup menjanjikan. Juga didorong oleh genjarnya isu halal untuk berbagai produk kuliner Kota Medan 
maka pastinya akan mendorong pihak pengelola untuk menyesuaikan strategi pemasarannya terutama pada parforman pemasaran. Perubahan strategi dalam pemasaran yang paling menonjol adalah parforman yang menampilkan unsurunsur ke-Islam seperti hijab yang digunakan oleh pekerja perempuan di outlet Bolu Meranti. Sebelumnya, pekerja perempuan di Bolu Meranti tidak memakai hijab.

Perubahan strategi pemasaran dengan mengedapankan parforman keIslaman berupa busana hijab bagi pekerja perempuan memang sedikit banyaknya mampu memberikan pengaruh terhadap nilai jual Bolu Meranti. Sebagaimana penuturan Ibu Zulhelna Mulia, "Di Medan ini yang jualan makanan kebanyakan orang China. Satu-satunya patokan kita untuk membeli makanan dengan melihat ada yang pakai jilbab saat mereka menjual makanannya. Karena kita juga tidak tahu apakah halal atau tidak, yang pasti karena yang menjual pakai jilbab, kita yakin saja bahwa makanan itu halal". ${ }^{20}$

Berdasarkan keterangan Ibu Zuhelna, setidaknya ada 3 (tiga) fakta yang dapat dianalisa terkait dengan pertumbuhan bisnis kuliner di Kota Medan. Pertama, dari sekian banyak outlet kuliner yang bertebaran diseluruh penjuru Kota Medan, mayoritas investornya adalah China dan beragama Non Muslim. kedua, untuk "menjerat" konsumen Muslim, hampir seluruh investor kuliner menampilkan busana kerja perempuannya dengan berhijab dan ketiga, kesadaran konsumen Muslim terhadap kehalalan sebuah produk makanan sangat minim sekali. Pekerja yang berjilbab ternyata menjadi pedoman konsumen Muslim untuk singgah guna berbelanja makanan yang diproduksi oleh Non Muslim.

Berhijab telah menjadi fenomena masyarakat moderen. Sebagai sebuah fenomena tentunya patut diperhatikan bahwa tengah terjadi sebuah pertanda adanya gerakan positif yang sangat kuat dalam ber-Islam. Sebab, dalam kehidupan sehari-hari, di tengah hiruk-pikuk kesibukan masyarakat modern, identitas ke-Islaman seorang perempuan yang tak berhijab hanya dapat terlihat saat ia bersholat dan atau berhaji. Ibadah-ibadah lainnya seperti puasa, zakat dan sedekah tidak kasat mata orang lain melihatnya.

Seorang perempuan yang berhijab disetiap perjalanan dinamika hidupnya pertanda bahwa perempuan tersebut tengah terus-menerus mendeklarasikan 


\section{Fenomena Hijab Dalam Bisnis Kuliner Di Kota Medan (Marzuti Isra, Sri 612 Sudiarti dan Isnaini Harahap)}

bahwa dirinya seorang Muslimah. Kalau berhijab ini disadari sebagai sebuah tuntunan syariah yang langsung datangnya dari Allah maka sesungguhnya perempuan tersebut di setiap hela nafasnya dan di setiap gerak langkahnya dilimpahkan berbagai kebaikan-kebaikan (pahala) yang hanya datangnya dari Allah swt. Bergitulah keutamaan berhijab yang pada setengah abad yang lalu di Indonesia masih dinilai sebuah busana yang aneh dan jauh dari image masyarakat yang beradab.

Fenomena hijab sebagai identitas perempuan Islam masuk dalam ranah ekonomi dimana pelaku pasarnya (investor) tidak beragama Islam. Terlihat bahwa yang berhijab sebagai tenaga kerja dan yang tak berhijab (Non Muslim) saling bersimbiosis untuk sama-sama survive. Pertanyaannya apakah hal ini pertanda kebangkitan ber-Islam dalam dunia ekonomi sehingga menggiring banyak ilmuan Islam merumuskan tentan ekonomi Islam/syariah atau ber-Islam tengah "ditungganngi" oleh investor Non Muslim untuk meraup keuntungan dari konsumen yang tengah gandrung akan simbol-simbol ke-Islaman.

Sebelum melangkah jauh untuk menjawab dan mengambil kesimpulan dari pertanyaan tersebut, mari dipahami kembali beberapa pengertian tentang ekonomi Islam ; menurut Muhammad Abdul Mannan bahwa ekonomi Islam merupakan ekonomi masyarakat yang diilhami oleh nilai-nilai Islam. ${ }^{21}$ Sementara Umer Chapra menyatakan bahwa yang dimaksud oleh Ekonomi Islam itu adalah membantu merealisasikan kesejahteraan manusia melalui alokasi dan distribusi sumber daya yang langka yang sesuai dengan maqashid tanpa terlalu membatasi kebebasan individu atau menciptakan ketidak-seimbangan makro ekonomi dan ekologi, atau melemahkan ikatan keluarga dan solidaritas sosial serta moral masyarakat. ${ }^{22}$ Pengertian yang lain juga disampaikan oleh Hasanuz Zaman bahwa ekonomi Islam dimaksudkan untuk mencegah ketidakadilan dalam penggalian dan penggunaan sumber daya material guna memenuhi kebutuhan manusia yang memungkinkan mereka melaksanakan kewajiban kepada Allah dan masyarakat. ${ }^{23}$

Dari tiga pengertian terhadap ekonomi Islam tersebut di atas, terdapat tiga sari yang menjadi pedoman dalam melaksakan ekonomi sebagaimana yang disyariatkan oleh Allah swt; Pertama, harus ada nilai-nilai Islam di dalamnya. 
Kedua, harus ada pencapain pada tingkat kesejahteraan manusia melalui alokasi dan distribusi sumber daya dan ketiga, harus ada keadilan dalam penggalian dan penggunaan sumber daya.

Merujuk pada fenomena hijab dibisnis kuliner Kota Medan seperti datadata tersebut di atas maka tersirat bahwa nilai-nilai Islam yang terwakili oleh perempuan-perempuan Islam yang berhijab saat bekerja sudah terlaksana pada takarannya masing-masing. Di Bika Ambon Zulaikha, nilai-nilai Islam telah masuk pada takaran yang lebih tinggi. Hal ini ditandai dengan perubahan sikap dan prilaku ber-Islam Hj. Mariani. Sebelum ia merintis usaha tidak berhijab, kemudian ia berhijab untuk menunjukkan identitas ke-Islamannya sebagai bentuk pembedaan dirinya dengan yang lain.

Dengan berhijab, usahanya pun sukses dan telah menjadi primadona seNusantara. Kesuksesan ini tidak membuat semangat ber-Islamnya stagnan atau bahkan bergerak mundur masuk kebudaya hedonisme masyarakat perkotaan yang high class. Justru semangat ber-Islamnya bergerak maju pada tingkat ketaqwaan yang tinggi sebagai wujud syukurnya. Tidak berhenti sampai disitu, $\mathrm{Hj}$. Mariani pun membagi syukurnya dengan merekruet banyak pekerja yang ia didik melalui pengajian-pengajian ke-Islaman secara rutin sehingga kesadaran ber-Islam juga ternanam kepada seluruh pekerjanya.

Tingkat kesejahteraan dan distribsi keadilan, tentunya juga tidak hanya dinikmati oleh $\mathrm{Hj}$. Mariani dan keluarganya saja di tengah kesuksesan usahanya. Usaha-usaha untuk meningkatkan kesejahteraan pekerjanya dilakukan dengan cara menyediakan fasilitas asrama lengkap dengan segala kebutuhannya yang tak berbayar kepada seluruh pekerjanya yang berasal dari luar kota di tengah biaya kost yang cukup tinggi di Kota Medan. Para pekerjanya pun tidak harus mengalokasikan sebagian gajinya untuk keperluan tempat tinggal, artinya karyawaan mendapatkan kesejahteraan dan keadilan dari keringat yang mereka keluarkan untuk membangun kebesaran Bika Ambon Zulaikha.

Sesungguhnya hal sama juga terjadi di Bolu Meranti, Mawar Bakery dan Majestyk. Hanya saja kesadaran ber-Islamnya stagnan pada tingkat strategi pemasaran. Peristiwa ini dapat dimaklumi karena owner outlet-outlet tersebut bukan bergama Islam. Tetapi kebijakan berhijab yang mereka lakukan kepada seluruh pekerja perempuan Islam telah menempatkan nilai-nilai Islam pada tempat 
yang layak. Kebijakan ini juga telah mendorong beberapa perempuan Islam yang tidak berhijab sebelumnya menjadi berhijab setelah ia bekerja di outlet-outlet tersebut.

Kebijakan berhijab juga telah memberikan kesempatan bagi perempuanperempuan Islam untuk masuk dalam lapangan kerja di saat yang lain kesulitan mendapatkan pekerjaan. Kebijakan Mawar Bakery misalanya yang hanya menerima perempuan Muslimah dan diwajibkan berhijab saat bekerja, bukankah hal ini dapat dilihat sebagai bentuk pendistribusian keadilan sebagaimana semangat dari nilai-nilai ekonomi Islam. Bukankah memfasilitasi seluruh pekerjanya untuk tinggal di asrama secara gratis turut memberikan andil dalam meningkatkan kesejahteraan para pekerja tersebut.

Berhijab untuk tujuan menjaga kebersihan dan higienis terhadap lingkungan dan makanan juga dapat dipandang sebagai implementasi nilai-nilai Islam dalam bisnis kuliner tersebut. Posisi menjaga kebersihan dalam Islam merupakan salah satu bagian terpenting, terutama saat beribadah. Menjaga kebersihan berarti mentaati perintah Allah swt ; "Sesungguhnya Allah SWT itu suci yang menyukai hal-hal yang suci, Dia Maha Bersih yang menyukai kebersihan, Dia Mahamulia yang menyukai kemuliaan, Dia Maha Indah yang menyukai keindahan, karena itu bersihkanlah tempat-tempatmu." (HR. Tirmizi). ${ }^{24}$

Rasulullah Muhammad saw diberbagai hadisnya banyak menyinggung soal pentingnya menjaga kebersihan, di antaranya adalah :

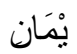

Artinya : Kebersihan itu sebagian dari iman. (HR. Ahmad). ${ }^{25}$

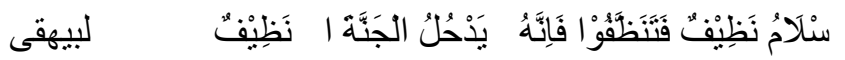

Artinya : Agama Islam itu (agama) yang bersih, maka hendaklah kamu menjaga kebersihan, karena sesungguhnya tidak akan masuk surga kecuali orang-orang yang bersih". (HR. Baihaqy). ${ }^{26}$ 
Hadit-hadis tersebut menjelaskan bahwa Islam adalah agama yang suci. Untuk itu umat Islam harus menjaga kebersihan, baik kebersihan jasmani maupun rohani. Orang yang selalu bersih dan suci mengindikasikan bahwa ia telah melaksanakan sebagian dari perintah agama dan akan memperoleh fasilitas berupa surga di akherat kelak.

Perempuan-perempuan Islam yang bekerja di outlet-outlet kuliner diperintahkan oleh para owner untuk berhijab guna menjaga kebersihan. Pada saat perintah itu dilaksanakan dengan kesadaran ber-Islam, sesungguhnya para pramusaji itu tengah menjalankan 3 (tiga) perintah Allah swt sekaligus, pertama, menjalankan perintah Allah untuk menutup aurat, kedua, melaksanakan perintah Allah dan Rasul untuk terbiasa menjaga kebersihan baik diri, makanan dan lingkungan dan ketiga, posisi para pramusaji tersebut berada dalam gerak $f i$ sabilillah karena dalam perjuangan untuk mengais rezaki yang halal.

Dengan demikian, berhijab sebagai tuntutan syariah dalam Islam dan berhijab sebagai sebuah strategi pasar telah beririsan satu dengan yang lainnya. Beririsan untuk saling mengambil keuntungan. Beririsan untuk dua kepentingan yang berbeda, satu sisi ada keuntungan terhadap syiar Islam melalui berhijab dan disisi lain dengan melekatkan simbol-simbol ke-Islaman dapat meraup keuntungan dari konsumen yang beragama Islam.

Kendatipun seluruh pekerja perempuan yang beragama Islam menggunakan hijab saat bekerja, namun kesadaran dan pehaman meraka terhadap hijab sangat beragam. Implementasi berhijabnya pun beragam. Dari data-data yang diperoleh oleh peniliti, maka setidaknya ada 3 (tiga) tingkatan kesadaran dalam berhijab: berhijab sebagai tuntunan agama, berhijab setelah bekerja, belum memiliki kesadaran.

\section{Kesimpulan}

Berhijab bagi pekerja perempuan dalam bisnis kuliner di Kota Medan merupakan sebuah kebijakan yang diberlakukan oleh para investor kuliner untuk dua tujuan, pertama, berhijab merupakan implementasi manajemen strategi pemasaran dalam rangka menarik konsumen Muslim yang paling besar di Kota Medan. Kedua, berhijab sebagai salah satu cara yang efektif untuk menjaga 


\section{Fenomena Hijab Dalam Bisnis Kuliner Di Kota Medan (Marzuti Isra, Sri 616 Sudiarti dan Isnaini Harahap)}

lingkungan yang bersih dan higenis terhadap semua produk kuliner. Khusus di outlet Bika Ambon Zulaikha, berhijab sudah bergerak kearah kesadaran yang ideologis (syariah). Kesadaran berhijab setiap pekerja perempuan di lingkungan usaha kuliner Kota Medan terdapat 3 (tiga) tingkat kesadaran dan pemahaman, pertama, pekerja yang memiliki kesadaran dan pemahaman yang ideologis jauh sebelum bekerja di outlet kuliner Kota Medan. Kedua, menemukan kesadaran dan pemahaman berhijab setelah bekerja di outlet kuliner Kota Medan karena dipengaruhi oleh lingkungannya dan selajutnya berhijab menjadi busana keseharian. Ketiga, kesadaran dan pemahaman berhijab sebatas sebagai penutup kepala untuk menjaga kebersihan produk kuliner dan belum menjadikan hijab sebagai busana keseharian. Identitas ke-Islaman seperti hijab dalam bisnis kuliner Kota Medan turut memberikan andil dalam membangun persepsi konsumen Islam untuk berbelanja di outlet kuliner tersebut. Bahwa konsumen Islam memiliki keyakinan dan kenyamanan terhadap jaminan higenis dan halal saat berbelanja kuliner di outlet yang pekerjanya menggunkan hijab.

Dalam bisnis kuliner di Kota Medan, para investor melihat bahwa potensi umat Islam sebagai konsumen cukup tinggi dan menjanjikan. Sehingga mereka berlomba-lomba menginvestasikan modalnya dalam bisnis tersebut dengan mengeksploitasi identitas ke-Islaman. Namun, investor dari kalangan Islam masih sangat sedikit. Oleh karena itu peneliti menyarankan untuk investor Islam masuk dalam bisnis kuliner di Kota Medan dengan tetap memperhatikan dan menjaga kualitas citra rasanya dan identitas ke-Islaman yang ideologis.

Pemahaman terhadap produk kuliner yang halal bagi konsumen Islam tergolong masih sangat rendah. Busana hijab yang dipakai pekerja perempuan di outlet kuliner Kota Medan menjadi pedoman untuk meyakini kehalalan sebuah produk kuliner. Oleh karena itu, peneliti menyarankan kepada Majelis Ulama Indonesia (MUI) atau pihak lain yang terkait dengan penerbitan sertifikasi halal kepada produk kuliner untuk diperketat dan secara berkesinambungan diteliti dan dikaji ulang untuk menjamin umat Islam mengkonsumsi produk yang halal. Keberhasilan investor meraup keuntungan dengan melekatkan identitas keIslaman dalam bisnisnya menunjukkan bahwa konsep ekonomi Islam merupakan keniscayaan di tengah pertumbuhan ekonomi dan pergerakan modernitas 
masyarakat perkotaan. Dengan demikian, peneliti menyarankan bahwa konsep ekonomi Islam yang mengedepankan identitas atau simbol-simbol ke-Islaman dengan berbagai fungsinya secara sistematis dan berkesinambungan disosialisasikan kepada investor dan masyarakat Islam. Tujuan sosialisasi ini untuk membangun kepercayaan dan keyakinan bahwa mengekspliotasi simbol Islam dalam berbisnis dapat menjamin keuntungan yang besar, baik di dunia maupun di akhirat.

\section{Catatan}

${ }^{1}$ Dzulmi Eldin, Pidato saat membuka Festival Kuliner 2016 di Atrium Hermes Place Medan, Jumat (30/9), diterbitkan di http://pemkomedan.go.id/artikel-15766

${ }^{2}$ Dalam dunia usaha, fashion memang sudah menjadi bagian penting dari gaya, trend, dan penampilan kesehariannya. Fashion memiliki arti suatu mode yang hidupnya tidak lama, yang mungkin menyangkut gaya bahasa, perilaku, hobby terhadap model pakaian tertentu (Sukanto, 2004). Fashion merupakan sebentuk perubahan yang dicirikan oleh rentang waktu yang singkat, sehingga fashion (mode) merupakan kekuatan dalam kebangkitan individualitas dengan mengizinkan seseorang untuk mengekspresikan diri dalam berpenampilan (Lipovetsky, 2010). Istilah fashion juga kerap digunakan sebagai sinonim dari istilah dandanan, gaya dan busana dalam masyarakat kontemporer barat akhir-akhir ini (Polhemus \& Procter, 2011).

3 Malcolm Barnard, Fashion Sebagai Komunikasi Cara Mengkomunikasikan Identitas Sosial, Seksual, Kelas, dan Gender, (Yogyakarta: Jalasutra, 2011), h. 100

${ }^{4}$ Haryanto Soedjatmiko, Saya Berbelanja, Maka Saya Ada Ketika Konsumsi dan Desain Menjadi Gaya Hidup Konsumeris, (Yogyakarta: Jalasutra, 2008), h. 63

${ }^{5}$ Gambaran dan penampakan kapitalisme tidak hanya dapat dilihat dari industri-industri besar yang menghasilkan produk-produk mewah, di mall-mall yang menawarkan produk mahal dan bermerek, yang menjadi simbol atau aksesoris penampilan yang berkelas, tetapi juga telah merambah keberbagai wilayah termasuk agama. Kapitalisme sedang memanfaatkan perdebatan paradigma internal dan sedang mengeksploitasi pemaknaan simbolik internal keberagamaan manusia modern dengan menggiring mereka masuk dalam budaya konsumsi massa. Karena secara simbolik budaya konsumerisme menjanjikan kepuasan untuk memenuhi hasrat dengan membangkitkan alam bawah sadar manusia untuk memusatkan perhatian pada pemujaan bendabenda, ikon-ikon dan simbol-simbol modernitas (Ibrahim, 2011).

${ }^{6}$ Dalam rangka memenuhi hasrat dari konsumerisme itu, berbagai even dan festival peragaan hijab yang melibatkan banyak desainer pun dilaksanakan sedemiian rupa. Kegiatan yang mirip-mirip pemilihan Putri Indonesia atau miss universe sudah dilakukan dan disponsori oleh produk-produk ternama yang ditayangkan langsung oleh stasiun televisi nasional, seperti acara Putri Hijab, Hijab Hun Sunsilk dan lain sebagainya.

${ }^{7}$ Khaerul Umam, Manajemen Organisasi, (Bandung:Penerbit Pustaka Setia,2012) h.193

${ }^{8}$ Ibid. h. 220

${ }^{9}$ Alma dan Priansa, Manajemen Bisnis Syariah. (Bandung : Alfabeta, 2014), h.342

${ }^{10}$ Ibid. h. 343

${ }^{11}$ Umam, Manajemen ......, h. 221

${ }^{12}$ Alma dan Priansa, Manajemen Bisnis Syariah. (Bandung : Alfabeta, 2014), h.359

${ }^{13}$ Quraish Shihab, Hijab Pakaian Perempuan Muslimah, (Jakarta: Lentera Hati, 2004), hal.

Ix

${ }^{14}$ Ibid, h. 41. 
${ }^{15}$ Ibid, h. 241

${ }^{16}$ Ahmad Gojali, tinggal di Jakarta, wawancara tanggal 9 Desember 2017

${ }^{17}$ Tika, masyarakat Kota Medan, wawancara tanggal 09 Desember 2017

${ }^{18}$ Cara ini dilakukan karena saat peneliti mengajukan izin meneliti kepihak pengelola terkait dengan judul penelitian, pihak pengelola/pemilik tidak memberikan izin meneliti kecuali hanya mewancari dari perwakilan pemilik dan dalam hal ini diwakili oleh salah seorang pengelola yaitu Sofia dan hanya sebatas memberikan informasi tentang sejarah singkat Bolu Meranti. Peneliti tidak diizinkan untuk berinteraksi langsung kepada pekerja perempuan. Fakta lapangan ini menyebabkan data-data dari sumber primer tidak dapat diperoleh secara sistematis. Informasi diperoleh melalui perbincangan singkat saat peneliti berbelanja.

${ }^{19}$ Sofia, wawancara tanggal 27 Desember 2017

${ }^{20}$ Zuhelna Mulia, konsumen Bolu Meranti, tinggal di Medan Helvetia, wawancara tanggal 27 Desember 2017.

${ }^{21}$ Mannan, Islamic Economics. h. 3

${ }^{22}$ M. Umer Chapra, The Future of Economics: An Islamic Perspective, (United Kingdom: The Islamic Foundation, 2000), h. 125.

${ }^{23}$ Zaman, "Definition of Islamic Economics". dalam Journal of Research in Islamic Economics, vol. 1, No. 2, 1984, h. . 49-50.

${ }^{24}$ Sembilan kitab hadis digital

25 Ibid

${ }^{26}$ Ibid

\section{Daftar Pustaka}

Abdurahman, Muslim. Islam yang Memihak. Yogyakarta: LKis. 2005.

Adlin, Alfatri. Menggeledah Hasrat: Sebuah Pendekatan Multi Perspektif. Yogyakarta: Jalasutra. 2006.

Anggraini, Nenny. Industri Kreatif. Jurnal Ekonomi Desember 2008, volume XIII No.3.

Arfa, Faisar Ananda. Perempuan Dalam Konsep Islam Modernis. Jakarta: Pustaka Firdaus. 2004.

Arif, Muhammad. Toward a Definition of Islamic Economics: Some Scientific Consideration. Journal of Research Islamic Economic Vol. 2 No. 2. 1985.

Barnard, Malcolm. Fashion Sebagai Komunikasi Cara Mengkomunikasikan Identitas Sosial, Seksual, Kelas, dan Gender. Yogyakarta: Jalasutra. 2011. Barnard, Malcolm. Fashion Sebagai Komunikasi Cara Mengkomunikasikan Identitas Sosial, Seksual, Kelas, dan Gender. Yogyakarta: Jalasutra. 2011. BPS Sumut tahun 2013. 
Buchari, Alma dan Donni Juni Priansa. Manajemen Bisnis Syariah. Bandung : Alfabeta. 2014.

Chapra, M. Umer. Islam and The Economic Challenge. Herndon USA: The Islamic Fondation and The International Institute of Islamic Thought. 1992.

Eldin, Dzulmi. Pidato saat membuka Festival Kuliner 2016 di Atrium Hermes Place Medan, Jumat (30/9), diterbitkan di http://pemkomedan.go.id/artikel15766.

Fadwa, El-Guindi. HIJAB Antara Kesalehan, Kesopanan dan Perlawanan. Jakarta: Serambi. 2006.

Fitri, Idatul dan Khasanah Nurul. 60 Kesalahan Dalam Berhijab. Jakarta: Basmalah. 2011.

Ibrahim, Idi Subandy. Budaya Populer Sebagai Komunikasi Dinamika Popscape dan Mediascape di Indonesia Kontemporer. Yogyakarta: Jalasutra. 2011.

Johnson, B, \& Christensen L, Educational Research. New Delhi: Sage Publications, Inc. 2011.

Mannan, Muhammad Abdul. Islamic Economics, Theory and Practice. India: Idarah Adabiyah. 1980.

McQuail, Denis. Teori Komunikasi Massa: Suatu Pengantar Edisi Kedua. Jakarta: Erlangga. 1989.

Miller, Gerald R. dan Nicholson Henry. Communication Inquiry, Reading. MA: Addison-Wesley. 1977.

Prasetia, Heru. Pakaian, Gaya, dan Identitas Perempuan Islam. Desantara Foundation: Depok. 2010.

Rahmat, Jalaluddin. Metode Penelitian Komunikasi Dilengkapi Contoh Analisis Statistik. Bandung: Rermaja Rosdakarya. 1984.

Ritzer, George \& Douglas J. Goodman, Teori Sosiologi Modern. Jakarta: Kencana Media Group. 2010.

Rosyadi, Ruslan. Metode Penelitian Publik Relation dan Komunikasi. Jakarta: Raja Grafindo Persada. 2004.

Sahputra, Dedi. Komunikasi Politik Partai Politik Islam. Yogyakarta: Orbit. 2016.

Salwen, Michael B dan Don W. Stacks, Mahwah. An Integrated Approach to Communication Theory and Research. NJ: Lawrence Erlbaum. 1996. 
Shahab, Husein. Hijab Menurut al-Qur'an dan al-Sunnah. Bandung: Mizania. 2013.

Shahab, Husein. Hijab Menurut al-Qur'an dan al-Sunnah. Bandung: Mizania 2013.

Shihab, Quraish. Hijab Pakaian Perempuan Muslimah. Jakarta: Lentera Hati. 2004.

Smart, Harold R. The Logic of Scince. New York: Appleton-Century-Cropts. 1931.

Soedjatmiko, Haryanto. Saya Berbelanja, Maka Saya Ada Ketika Konsumsi dan Desain Menjadi Gaya Hidup Konsumeris. Yogyakarta: Jalasutra. 2008.

Sofjan, Assauri. Manajemen Pemasaran. Jakarta: Raja Grafindo Persada. 2014.

Subandy, Ibrahim Idi. Budaya Populer Sebagai Komunikasi Dinamika Popscape dan Mediascape di Indonesia Kontemporer. Yogyakarta: Jalasutra. 2011.

Sugiyono. Metode Penelitian Kombinasi (Mixed Methods). Bandung: Alfabeta. 2014.

Tjiptono, Fandy dan Gregorius Chandra. Pemasaran Strategik. Yogyakarta : Andi Publisher. 2012.

Umam, Khaerul. Manajemen Organisasi. Bandung: Penerbit Pustaka Setia. 2012.

Widiyawati, Ari. Pengaruh Masyarakat Islam dalam Pertumbuhan Ekonomi Analisis Industri Fesyen Muslim. Jurnal COMMUNITY DEVELOPMENT Volume 1, Nomor 2, Desember 2016.

Zaman, S.M.H. Definition of Islamic Economics. Journal of Research in Islamic Economics, vol. 1, No. 2, 1984.

Gojali, Ahmad. “Interview konsumen Bika Ambon Zulaikha Medan”. 9 Desember 2017.

Tika. "Interview konsumen Bika Ambon Zulaikha Medan”. 9 Desember 2017.

Mulia, Zuhelna. "Interview konsumen Bika Ambon Zulaikha Medan". 27 Desember 2017.

Hj. Mariani, "Interview pemilik Bika Ambon Zulaikha Medan”, 05 Desember 2017.

Sofia, “Interview pekerja Bolu Meranti Medan”, 27 Desember 2017. 